\title{
UPAYA MENINGKATKAN HASIL BELAJAR EKONOMI MENGGUNAKAN MODEL PEMBELAJARAN MAKE A MATCH PADA KELAS X IPS 1 SMA NEGERI 1 KATINGAN HILIR
}

\author{
Oleh \\ Putu Tiara Kumala Sinta,* Bulkani** \\ Email: bulkani@gmail.com
}

\begin{abstract}
The researcher aims to find out the activities and find out the improvement in participants' economic learning outcomes. This type of research uses Classroom Action Research (CAR). As for the subjects in this study were students of class X IPS 1 in Katingan Hilir 1 Senior High School totaling 22 students. The instruments used were observation sheets and learning outcomes test questions. The data analysis technique used is qualitative and quantitative. The results of the study show that: (1) The activities of students during the economic learning process are more active. Learning activity cycle I obtained an average score of 2.7 with fairly good criteria, and in the second cycle, the score increased to 3.5 with good criteria. (2) There is an increase in economic learning outcomes after applying the Make a Match learning model. In the first cycle the learning outcomes of students complete with an average of 65 with a data percentage of $64 \%$. Then there is an increase in the second cycle, with an average score of 80 with a percentage of $86 \%$.
\end{abstract}

(C) Muhammadiyah University Palangkaraya

Keywords: Economic Learning Outcomes, Make a Match Model

\begin{abstract}
ABSTRAK
Peneliti ini bertujuan untuk mengetahui aktivitas dan mengetahui peningkatan hasil belajar Ekonomi peserta. Jenis penelitian ini menggunakan Peneltian Tindakan Kelas (PTK). Adapun yang menjadi subjek dalam penelitian ini adalah peserta didik kelas X IPS 1 SMA Negeri 1 Katingan Hilir yang berjumlah 22 orang peserta didik. Instrumen yang digunakan lembar observasi dan soal tes hasil belajar. Teknik analisis data yang digunakan adalah secara kualitatif dan kuantitatif. Hasil penelitian menunjukan bahwa: (1) Aktivitas peserta didik selama proses pembelajaran ekonomi lebih aktif. Aktivitas belajar siklus I diperoleh skor rata-rata 2,7 dengan kriteria cukup baik, dan pada siklus II , skor meningkat menjadi 3,5 dengan kriteria baik . (2) Ada peningkatan hasil belajar ekonomi setelah menerapkan model pembelajaran Make a Match. Pada siklus I hasil belajar peserta didik tuntas dengan rata-rata 65 dengan data persentase $64 \%$. Kemudian adanya peningkatan pada siklus II, dengan skor rata-rata 80 dengan persentase $86 \%$.
\end{abstract}

(C) Universitas Muhammadiyah Palangkaraya

Kata Kunci: Hasil Belajar Ekonomi, Model Make a Match

Putu Tiara Kumala sinta* Mahasiswa FKIP UM Palangkaaraya

Bulkani** Dosen Universitas Muhammadiyah Palangkaraya 


\section{PENDAHULUAN}

Pendidikan merupakan penggerak ilmu pengetahuan bahkan dapat dikatakan sebagai kunci keberhasilan pembangunan, dan pendidikan merupakan kebutuhan mendasar manusia dalam meningkatkan sumber daya manusia. Pendidikan bukan hanya untuk menambah pengetahuan, namun lebih dari itu pendidikan merupakan sarana untuk membentuk kepribadian manusia kearah peradaban yang mulia sesuai dengan sila-sila Pancasila. Untuk itu pelaksanaan pendidikan diusahakan berjalan secara berkesinambungan atau terus menerus meningkat seiring perkembangan zaman. Dalam rangka meningkatkan kualitas pendidikan dan pengajaran, dengan maksud untuk membina pribadi-pribadi kreatifitas yang mantap dalam usaha mengembangkan pengetahuan, ketrampilan dan sikap yang mengacu pada usaha pembentukan pribadi manusia dalam membangun bangsa. Pada dasarnya pembelajaran merupakan kegiatan terencana yang mengkondisikan/merangsang seseorang bisa belajar dengan baik agar sesuai dengan tujuan pembelajaran. Jadi, model pembelajaran merupakan suatu perencanaan atau pola yang digunakan sebagai pedoman dalam merencanakan pembelajaran di kelas ataupun dalam pembelajaran tutorial.

Menurut Joice (Trianto,2014:51-52) yaitu: Model pembelajaran adalah rencana dari pola yang dapat kita gunakan untuk merancang model pembelajaran yang digunakan di kelas ataupun tutorial untuk menentukan materi pembelajaran atau perangkatperangkat pembelajaran seperti bukubuku, film-film, program media komputer dan kurikulum ( sebagai kursus untuk anak belajar). Sedangkan menurut Soekunto (Trianto, 2010:74) menyatakan: Model pembelajaran adalah kerangka konseptual yang melukiskan prosedur yang sistematis dalam mengkoordinasikan pengalaman belajar untuk mencapai tujuan belajar dan berfungsi sebagai pedoman bagi perancang pembelajaran dan para pengajar dalam merencanakan aktivitas belajar mengajar.

Berdasarkan pengertian tersebut di atas dapat disimpulkan bahwa, model pembelajaran adalah suatu perencanaan pembelajaran dan kerangka (pedoman) pembelajaran yang tersusun secara sistematis untuk meningkatkan aktivitas belajar mengajar guna membantu tercapainya tujuan pembelajaran itu sendiri.

Menurut Slameto (2010:2) Belajar adalah suatu proses usaha yang dilakukan seseorang untuk memperoleh suatu perubahan tingkah laku yang secara keseluruhan, sebagai hasil pengalamannya sendiri dalam interaksi dengan lingkungannya.

Dalam belajar mengajar hal yang terpenting adalah tahapan, karena ini lah yang menentukan tercapai atau tidaknya tujuan belajar. Jika peserta didik bisa melewati sebuah tahapan, maka ia akan sangat berpotensi untuk melewati tahapan selanjutnya. Tercapai atau tidaknya proses belajar mengajar ditandai dengan adanya perubahan dari peserta didik, terutama perubahan pada 
tingkah laku dan kualitas pribadi itu sendiri. Perubahan tingkah laku akan menyangkut tiga faktor dalam penilaian yaitu kognitif, afektif dan psikomotor.

Dalam proses belajar mengajar ada banyak faktor yang mempengaruhi tercapainya suatu tujuan pembelajaran. Pada umumnya faktor yang mempengaruhinya itu seperti faktor motivasi, lingkungan, bakat, dan fasilitas. Bila faktor-faktor tersebut mendukung proses belajar mengajar, maka peserta didik tidak akan mengalami hambatan dalam proses belajar mengajar begitu pula sebaliknya bila faktor tersebut kurang mendukung akibatnya proses belajar mengajar peserta didik akan terpengaruh atau mengalami hambatan.

Maka disinilah peran penting seorang pendidik, sebagai komponen utama dalam proses belajar sangat menentukan untuk tercapainya hasil belajar yang diinginkan. Penyampaian materi pelajaran yang sesuai dengan tuntutan kurikulum, penggunaan metode, model serta media pembelajaran yang sesuai akan menentukan tinggi rendahnya hasil dan prestasi belajar siswa. Selain itu juga perlu diperhatikan kemampuan pendidik dalam memahami karakteristik siswa di kelas. Dimana pendidik dituntut untuk menciptakan iklim belajar dengan adanya komunikasi dua arah dengan peserta didik yaitu dalam belajar, peserta didik dapat mengemukakan pendapatnya tanpa rasa takut ada tekanan. Pendidik juga juga bisa melibatkan seluruh peserta didik dalam proses pembelajaran, salah satunya dengan menggunakan model pembelajaran, maka pembelajaran akan menjadi lebih aktif dan menyenangkan.

Keberadaan model pembelajaran sangat diperlukan dalam membantu tugas-tugas pendidik. Salah satu keprofesionalan guru adalah harus dapat memilih dan mengembangkan model pembelajaran. Tiap-tiap model pembelajaran memiliki kekuatankekuatan yang positif dan sinergi yang dapat merubah sikap dan perilaku. Sehubungan denga hal itu, peran salah satu model pembelajaran Make a Match sangat dibutuhkan dalam pembelajaran, dimana dalam perkembangan saat ini, model pembelajaran bukan lagi dipandang sekedar alat bantu tetapi merupakan bagian yang integral dalam sistem pendidikan dan pembelajaran.

Menurut Isjoni

(2011:112) berpendapat bahwa Make a Match merupakan model pembelajaran yang dimana siswa mencari pasangan sambil belajar mengenai suatu konsep atau topik dalam suasana yang menyenangkan. Dengan demikian akan tercipta suasana pembelajaran yang menyenangkan sehingga peserta didik dapat mengoptimalkan potensi yang dimiliki dan hasil belajar ekonomi akan lebih meningkat.

Dari pendapat diatas dapat disimpulkan bahwa model pembelajaran Make a Match adalah model pembelajaran yang melatih peserta didik untuk berani bersosialisasi dan turut aktif dalam proses pembelajaran.

Pada kenyataannya yang terjadi pada pembelajaran di SMA Negeri 1 Katingan Hilir di Kabupaten Katingan. Peserta didik terlihat kurang termotivasi, minat belajar rendah dan 
cenderung melakukan hal yang diluar kewajibannya sebagai seorang peserta didik, baik dalam proses pembelajaran di kelas ataupun di luar. Peserta didik juga kurang aktif secara keseluruhan dalam proses pembelajaran. Peserta didik juga kurang memanfaatkan sarana dan fasilitas yang ada pada sekolah. Hal ini terlihat dari nilai yang mereka peroleh, baik nilai tugas harian maupun nilai UTS (Ulangan Tengah Semester). Pada saat peneliti melakukan observasi pada 10 Januari 2018 peneliti melihat dengan KKM 70, nilai yang diperoleh peserta didik rata-rata dibawah nilai KKM, dari 22 peserta didik hanya 10 peserta didik yang tuntas dan sisanya 12 peserta didik belum tuntas. Jika hal ini berlanjut terus menerus jelas akan berdampak pada hasil belajar yang mereka raih, dan tidak sedikit diantara mereka yang memperoleh hasil yang tidak maksimal.

Maka dengan itu peneliti berkesimpulan untuk menerapkan sebuah metode dan model pembelajaran yang akan meningkatkan hasil belajar peserta didik. Model yang akan peneliti gunakan adalah model pembelajaran Make a Match. Alasan peneliti memilih model pembelajaran Make a Match karena masih jarang di gunakan di sekolah, dan model Make a Match diharapkan dapat meningkatkan hasil belajar kelas $\mathrm{X}$ IPS 1 SMAN-1 Katingan Hilir.

Berdasarkan uraian yang dipaparkan di atas,maka peneliti akan menggunakan metode pembelajaran "Make a Match" atau mencari pasangan, dalam penelitian tindakan kelas pada X IPS 1 SMA Negeri 1
Katingan Hilir. Penelitian ini berjudul Upaya Meningkatkan Hasil Belajar Ekonomi Menggunakan Model Pembelajaran Make a Match Pada Kelas $X$ IPS 1 SMA Negeri 1 Katingan Hilir Tahun Pelajaran 2017/2018.

\section{METODE PENELITIAN}

Jenis penelitian yang dilakukan adalah Penilitian Tindakan Kelas (PTK). Menurut Kunandar (2012:44) menyatakan bahwa: Penelitian Tindakan Kelas (PTK) adalah suatu penelitian tindakan (action research) yang dilakukan oleh guru yang sekaligus sebagai peneliti di kelasnya atau bersama-sama dengan orang lain (kolaborasi) dengan jalan merancang, melaksanakan dan merefleksikan tindakan secara kolaboratif dan partisipatif yang bertujuan untuk memperbaiki atau meningkatkan mutu (kualitas) proses pembelajaran dikelasnya melalui tindakan (treatment) tertentu dalam suatu siklus.

Sedangkan menurut Paizaludin dan Ermalinda (2016:7): Penelitian tindakan kelas adalah suatu kegiatan penelitian dengan mencermati sebuah kegiatan belajar yang di berikan tindakan, yang secara sengaja dimunculkan dalam sebuah kelas, yang bertujuan memecahkan masalah atau meningkatkan mutu pelajaran di kelas tersebut.

Sementara itu dilakukannya PTK di antaranya untuk meningkatkan kualitas pendidikan atau pengajaran yang diselenggarakan oleh pendidik atau peneliti itu sendiri, yang 
dampaknya diharapkan tidak ada lagi permasalahan yang mengganjal di kelas.

Dari beberapa pendapat di atas, dapat disimpulkan bahwa penelitian tindakan kelas adalah penelitian yang dilakukan guru secara sistematis dalam kegiatan belajar berupa sebuah tindakan dalam sebuah kelas secara bersamaan melalui refleksi diri untuk meningkatkan hasil belajar peserta didik. Arikunto Suharsimi ( 2002 ). Prinsip Penelitian Tindakan Kelas:

a. Kegiatan nyata dalam situasi rutin

b. Adanya kesadaran diri untuk memperbaikin kinerja

c. Swot sebagai dasar berpijak

d. Upaya empiris dan sistemik

e. Ikuti prinsip SMART dalam perencanaan

\section{HASIL DAN PEMBAHASAN}

Hasil belajar yang diperoleh berdasarkan hasil tes pada peserta didik kelas $\mathrm{X}$ IPS 1 SMA NEGERI 1 KATINGAN HILIR yang berjumlah 22 orang peserta didik dengan menerapkan model Make a Match telah diterapkan pada peserta didik dalam proses pembelajaran, hal ini ditandai oleh:

1. Hasil Pengamatan Guru dan Peserta Didik

Hasil pengamatan guru dan peserta didik dalam pembelajaran Ekonomi pada materi manajemen dengan menggunakan model pembelajaran Make a Match saat pembelajaran berlangsung dicatat oleh dua orang observer yaitu seorang guru mata pelajaran ekonomi dan satu orang teman sejawat yang tergambar dalam tabel berikut

\section{Tabel 1}

Rekapitulasi Data Pengamatan Aktivitas Guru dan Pesrta Didik Dalam Pembelajaran Ekonomi Pada Materi Manajemen Kelas X IPS 1 SMAN 1

Katingan Hilir

\begin{tabular}{|c|c|c|c|}
\hline No & Aktivitas & \multicolumn{2}{|c|}{$\begin{array}{c}\text { Nilai Rata- } \\
\text { Rata }\end{array}$} \\
\hline & & $\begin{array}{c}\text { Siklus } \\
\text { I }\end{array}$ & $\begin{array}{c}\text { Siklus } \\
\text { II }\end{array}$ \\
\hline 1. & $\begin{array}{c}\text { Aktivitas } \\
\text { Guru }\end{array}$ & 2,7 & 3,5 \\
\hline 2. & $\begin{array}{c}\text { Aktivitas } \\
\text { Peserta } \\
\text { Didik }\end{array}$ & 2,8 & 3,4 \\
\hline
\end{tabular}

Berdasarkan tabel di atas, melalui pembelajaran Ekonomi menggunakan model pembelajaran Make a Match dengan materi manajemen oleh peneliti di kelas X IPS 1 SMAN 1 Katingan Hilir aktivitas guru dan peserta didik menunjukan perkembangan baik.

2. Hasil Belajar Perta Didik

Hasil belajar yang diperoleh berdasarkan hasil tes pada peserta didik kelas X IPS 1 SMAN 1 Katingan Hilir dengan menggunakan model pembelajaran Make a Match, rekapitulasi data dapat dilihat sebagai berikut:

\section{Tabel 2}

Presentase Hasil belajar Peserta Didik

Dengan Menggunakan Model

Pembelajaran Make a Match

\begin{tabular}{|l|l|l|l|}
\hline No & $\begin{array}{l}\text { Pre- } \\
\text { Test }\end{array}$ & Siklus I & Siklus II \\
\hline 1 & $23 \%$ & $64 \%$ & $86 \%$ \\
\hline
\end{tabular}

Berdasarkan tabel diatas, dapat diketahui bahwa pada tes awal rata-rata peserta didik memperoleh nilai 49. Nilai ini masih kurang jauh dari kriteria ketuntasan minimal yang ditentukan 
yaitu 70. Hasil ketuntasan secara klasikal minimal $85 \%$. Kemudian pada siklus I peserta didik mengalami sedikit peningkatan, nilai rata-rata 65 dan peningkatan secara klasikalnya $64 \%$ masih belum mencapai nilai ketuntasan klasikal. Kemudian pada siklus II peserta didik mengalami peningkatan nilai rata-rata 80 dengan peningkatan secara klasikasl $86 \%$, dan sudah mencapai nilai ketuntasan secara klasikal.

Berdasarkan hasil rekapitulasi nilai pengamat di atas, maka dapat diketahui melalui penggunaan model pembelajaran Make a Match dengan materi manajemen pada kelas X IPS 1 SMAN 1 Katingan Hilir tahun pelajaran 2017/2018 menunjukan aktivitas dan peningkatan hasil belajar peserta didik pada mata pelajaran Ekonomi.

\section{KESIMPULAN}

Berdasarkan hasil penelitian dan pembahasan pada BAB IV, maka diambil kesimpulan sebagai berikut:

1. Aktivitas peserta didik selama proses pembelajaran ekonomi dengan menerapkan model pembelajaran Make a Match pada kelas X IPS 1 SMAN 1 Katingan Hilir lebih aktif. Aktivitas belajar siklus I diperoleh skor rata-rata 2,7 dengan kriteria cukup baik, dan pada siklus II , skor meningkat menjadi 3,5 dengan kriteria baik.

2. Ada peningkatan hasil belajar ekonomi setelah menerapkan model pembelajaran Make a Match pada kelas X IPS 1 SMAN 1 Katingan Hilir. Pada siklus I hasil belajar peserta didik tuntas dengan rata-rata 65 dengan data persentase $64 \%$. Kemudian adanya peningkatan pada siklus II, dengan skor ratarata 80 dengan persentase $86 \%$.

\section{DAFTAR PUSTAKA}

Isjoni. (2011). Pembelajaran Kooperatif Meningkatkan Kecerdasan Komunikasi Antar Peserta Didik. Yogyakarta: Pustaka Pelajar.

Kunandar. (2012). Langkah Mudah Penelitian Tindakan Kelas Sebagai Pengembangan Profesi Guru. Jakarta: PT Raja Grafindo Perdasa.

Paizaludin dan Ermalinda. (2016). Penelitian Tindakan Kelas. Bandung: Alfabeta.

Slameto. (2010). Belajar dan faktorfaktor yang mempengaruhinya. Jakarta: PT Rineka Cipta.

Suharsimi, Arikunto, dkk. (2002). Prinsip Penelitian Tindakan Kelas, Jakarta: PT Bumi Aksara

Trianto, 2010. Mendesain Model Pembelajaran InovatifProgresif. Jakarta: Kencana Prenada Media Group.

Trianto. (2014). Model Pembelajaran Terpadu. Jakarta: PT Bumi Aksara 